ELEOS: Jurnal Teologi dan Pendidikan Agama Kristen

Sekolah Tinggi Teologi Kalvari Manado

Volume 1, Nomor 1 Edisi Juli 2021 (Hal. 50-62)

https://sttkalvari.ac.id/ojs/index.php/eleos/index

\title{
Peran Pendampingan Orang Tua Dalam Pembelajaran Anak Usia Dini Selamat Belajar Dari Rumah di Masa Pandemi Covid-19
}

\author{
${ }^{1}$ Alfred Bunga Data, ${ }^{2}$ Talizaro Tafonao, ${ }^{3}$ Dewi Lidya Sidabutar, \\ ${ }^{4}$ Rini Sumanti Sapalakkai \\ ${ }^{1,2,3,4}$ Sekolah Tinggi Teologi Real Batam. \\ 1'alfredbunga69@gmail.com, 2talizarotafonao@gmail.com, \\ ${ }^{3}$ dewilidyasidabutar30@gmail.com, ${ }^{4}$ rinigenovita@gmail.com
}

\begin{abstract}
The Covid-19 pandemic requires children to study at home. All student learning activities are carried out at home with guidance from parents. So that the role of parents in educating children is in the first place. Parents are the main responsibility for the education of their children. The purpose of writing this article is to see how the efforts made by parents in accompanying their children during the pandemic. The research method used in this research is descriptive qualitative method. The method is, the method used is based on data obtained from the research field. In this study, besides wanting to see the child's learning process, the role and parenting pattern or mentoring of parents to their children during online learning that you want to observe carefully. Parents can apply teaching methods that involve daily activities such as making food, cleaning the house, or other things that can be created with the material being studied by the child. From the results of research on the role of parents in accompanying children during online learning, they still find various obstacles ranging from a lack of understanding of the condition of each child.
\end{abstract}

Keywords: The Role of Parents, Online Learning, Covid-19

\begin{abstract}
Abstrak
Adanya pandemi Covid-19 mengharuskan anak untuk belajar di rumah. Seluruh kegiatan belajar siswa dilaksanakan di rumah dengan bimbingan dari orang orang tua. Sehingga peranan orang tua dalam mendidik anak berada pada urutan pertama. Orang tua merupakan penanggung jawab utama dalam pendidikan anak-anaknya. Tujuan penulisan artikel ini adalah melihat bagaimana upaya-upaya yang dilakukan oleh orang tua dalam mendampingi anak selama pandemi. Metode penelitian yang digunakan dalam penelitian ini adalah metode kualitatif deskriptif. Metode tersebut merupakan, metode yang digunakan berdasarkan data yang diperoleh dari lapangan penelitian. dalam penelitian ini selain ingin melihat proses pembelajaran anak peran dan pola asuh atau pendampingan orang tua kepada anak anaknya selama pembelajaran daring yang ingin diamati secara seksama. Orang tua bisa menerapkan metode pengajaran yang melibatkan
\end{abstract}


kegiatan sehari-hari seperti membuat makanan, membersihkan rumah, atau lainnya yang bisa dikreasikan dengan materi yang sedang dipelajari oleh anak. Dari hasil penelitian peran orang tua dalam mendampingi anak selama pembelajaran daring masih menemukan berbagai kendala mulai dari kurangnya pemahaman akan kondisi anak masing-masing.

Kata Kunci: Peran Orang Tua, Pembelajaran Daring, Covid-19.

\section{Pendahuluan}

Virus corona atau Covid-19 pertama kali muncul atau ditemukan di kota Wuhan, China pada akhir tahun 2019 lalu. Virus ini belum juga ditemukan penawarnya hingga kini tidak terkendali. Sudah lebih dari 200 negara yang ada di dunia melaporkan adanya kasus virus corona. Pandemi Covid-19 merupakan musibah yang memilukan bagi seluruh penduduk bumi. Seluruh kehidupan manusia di bumi terganggu, tanpa kecuali pendidikan. Banyak negara memutuskan menutup sekolah, perguruan tinggi maupun universitas, termasuk negara Indonesia.

Seluruh negara di dunia kini melakukan berbagai upaya untuk mencegah penyebaran Covid-19 agar tidak terjadi pertambahan pasien positif yang semakin melonjak setiap harinya, hal ini terjadi karena belum ditemukannya obat atau pun vaksin untuk penyakit ini. Penyebaran Covid-19 ini membuat beberapa dampak perubahan besar yang dirasakan oleh seluruh masyarakat Indonesia, mulai dari sektor ekonomi hingga sektor Pendidikan. Berdasarkan Surat Edaran Nomor 4 Tahun 2020 yang dikeluarkan Menteri Pendidikan dan Kebudayaan Republik Indonesia Tentang Pelaksanaan Kebijakan Pendidikan Dalam Masa Darurat Penyebaran Coronavirus Disease (Covid-19) dijelaskan bahwa proses belajar dilaksanakan di rumah melalui pembelajaran daring/jarak jauh. ${ }^{1}$ Kebijakan pembelajaran daring ini dilakukan untuk mencegah penyebaran Covid-19 yang semakin cepat karena dapat menular melalui droplet dan kontak fisik.

Pendidikan ialah proses pembelajaran dengan tujuan untuk dikembangkannya bakat pada diri anak, baik itu bersifat kepribadian, kecerdasan, spritual dan keagamaan. ${ }^{2}$ Pendidikan merupakan hal yang tidak dapat dipisahkan dari kehidupan. Pendidikan dapat dijadikan sebagai alat ukur pengembangan potensi peserta didik. Hal tersebut dilihat dari beberapa aspek, diantaranya kecerdasan, akhlak, kepribadian serta keterampilan yang mereka miliki. Potensipotensi tersebut berupa penanaman karakter yang harus dimiliki oleh peserta didik. Baik dalam kehidupan sehari-hari maupun dalam dunia pendidikan.

Keluarga merupakan lingkungan pertama bagi anak. Di lingkungan keluarga inilah anak mendapatkan pendidikan yang pertama dan utama. Tugas utama keluarga adalah sebagai peletak

\footnotetext{
${ }^{1}$ Puspita Ria Sari, Nabila Bunnanditya Tusyantari, and Meidawati Suswandari, "Dampak Pembelajaran Daring Bagi Siswa Sekolah Dasar Selama Selama Covid-19 Universitas Veteran Bangun Nusantara , Sukoharjo," Prima Magistra: Jurnal Ilmiah Kependidikan 2, no. 1 (2021): 9-15.

${ }^{2}$ Harri Jumarto Suriadi, Firman Firman, and Riska Ahmad, "Analisis Problema Pembelajaran Daring Terhadap Pendidikan Karakter Peserta Didik,” Edukatif : Jurnal Ilmu Pendidikan 3, no. 1 (2021): 165-173.
} 
dasar bagi pendidikan moral-agama dan karakter anak. Khususnya dalam pendidikan anak usia dini menurut Zuharini, dkk lingkungan keluarga menjadi tempat meletakkan dasar-dasar kepribadian bagi anak usia dini. Pada usia inilah anak sangat peka terhadap pengaruh dari lingkungan sekitarnya. ${ }^{3}$ Orang tua merupakan penanggung jawab utama dalam pendidikan anak-anaknya. Orang tua juga berperan dalam penentuan masa depan anak-anaknya. Pendidikan seorang anak dimulai dari lingkungan keluarga yang menjadi hal penting dalam pembentukan karakter anak. Pendidikan di luar bukan berarti orang tua dapat begitu saja melepas anakanaknya. Orang tua juga harus berperan untuk mengawasi, mengarahkan, dan memberi edukasi bagi anak-anak dengan baik. Selain itu, orang tua juga dapat mengetahui sampai dimana kemampuan anak-anaknya dalam bidang pendidikan. Di sisi lain pendampingan orang tua dalam pembelajaran dari rumah sangat membantu anak dalam momen belajar juga akan membangun komunikasi yang intens dengan anak. Komunikasi yang intens ini akan membangun kreativitas anak lewat berbagai aktivitas bersama yang bermanfaat. ${ }^{4}$ Peran orang tua dalam pendidikan anak tersebut adalah sebagian yang dapat dilihat secara langsung. Dibalik peran tersebut, orang tua di rumah juga memiliki keterbatasan-keterbatasan yang menghambat perannya untuk membantu anak dalam pembelajaran. Keterbatasan tersebut diantaranya keterbatasan ilmu, serta kesibukan orang tua yang kadang tidak bisa diprediksi atau ditunda. Sehingga orang tua merasa kurang maksimal dalam membimbing anaknya. Maka dari itu, kita menghimbau untuk orang tua agar lebih memperhatikan lagi dalam segi belajar anak. Cari metode yang bisa diterapkan dengan mudah untuk mendidik anak dirumah. Seperti meminta bantuan kepada saudara sekitar atau memberi les privat kepada anak sesuai dengan kemampuan finansial. Dengan ini, anak akan belajar secara interen dan bisa mendalami materi pelajaran yang dijelaskan oleh pendidik. Karna pendidik bukan hanya seorang guru melainkan setiap orang yang mampu membagikan ilmu dan pengalaman yang dimiliki. Oleh karena itu orang tua dari peserta didik harap bisa mengambil langkah yang tepat supaya peserta didik bisa terjamin dalam segi belajar dan menerapkan ilmu yang diajarkan. Supaya peserta didik merasa nyaman dalam belajar. Maka dari itu, para orang tua pendidik tanyakan kepada pendidik mengenai sistem belajar yang menurut mereka bisa menyesuaikan dan memahami setiap pelajaran yang diajarkan oleh pendidik. Setiap pendidik memiliki kelebihan dan kekurangan dalam segi pembelajaran. baik tentang materi perhitungan matematika atau tentang ilmu pengetahuan dan sejarah. Hal itu dikarenakan kekurangnya minat peserta didik pada pelajaran tertentu. Biasanya peserta didik hanya menyukai satu pelajaran dari banyak pelajaran yang ada di sekolah. karena itu orang tua dari peserta didik harus lebih mengetahui pelajaran apa yang disukai oleh peserta didik dan apa yang tidak disukai oleh peserta didik. Dengan cara menanyakan kepada peserta didik dan mencari solusi yang terbaik kepada mereka.

\footnotetext{
${ }^{3}$ Selfi Lailiyatul Iftitah and Mardiyana Faridhatul Anawaty, "Peran Orang Tua Dalam Mendampingi Anak Di Rumah Selama Pandemi Covid-19," JCE (Journal of Childhood Education) 4, no. 2 (2020): 71.

${ }^{4}$ Wiwin Yulianingsih et al., "Keterlibatan Orangtua Dalam Pendampingan Belajar Anak Selama Masa Pandemi Covid-19," Jurnal Obsesi : Jurnal Pendidikan Anak Usia Dini 5, no. 2 (2020): 1138-1150.
} 
Peran orang tua siswa sangat penting dalam pembelajaran daring karena orang tua yang harus membimbing dan mengawasi anak-anak saat belajar di rumah. Menurut Hutahaean dan Tafonao bahwa di masa pandemi ini orang tua sangat dibutuhkan dalam dalam mendampingi pembelajaran anak di rumah. ${ }^{5}$ Namun, tidak sedikit orang tua yang merasa kesulitan saat mendampingi anaknya saat pembelajaran daring tersebut. Banyak orang tua yang tidak menguasai cara penggunaan teknologi informasi yang digunakan sebagai media dalam pembelajaran daring. Selain itu, kendala yang dihadapi para orang tua adalah adanya pengeluaran kuota internet yang bertambah karena pembelajaran daring ini memerlukan jaringan internet dan kuota. Kendala selanjutnya yang dirasakan orang tua yaitu mereka tidak dapat meluangkan waktu yang banyak untuk mendampingi anaknya belajar, karena orang tua sendiri mempunyai kesibukannya masing-masing, apalagi bagi orang tua yang harus berkerja di luar rumah karena bergantung pada penghasilan harian. Selain itu, kendala yang dihadapi saat mendampingi anak dalam pembelajaran daring yaitu orang tua merasa kewalahan karena tidak memahami materi pelajaran sekolah anaknya, apalagi bagi orang tuanya yang tidak mempunyai latar belakang pendidikan yang tinggi. Haerudin menyatakan bahwa, terdapat kendala dalam pelaksanaan pembelajaran daring yaitu keterbatasan dalam penggunaan teknologi dan pengetahuan dari orang tua. ${ }^{6}$ Pembelajaran daring memiliki tantangan tersendiri bagi orang tua siswa, mereka dituntut untuk selalu membimbing dan mendampingi anak dalam belajar. Dalam pengamatan Manurung dan Tafonao di lapangan bahwa apa yang terjadi di atas benar-benar terjadi dimana pembelajaran online ini bukan hal mudah untuk dijalani oleh siswa, orang tua dan guru. ${ }^{7}$ Tetapi mau tidak mau orang tua atau wali peserta didik diharapkan menjadi pendidik (guru) dan mengetahui pelajaran apa yang bisa diajarkan secara mendalam kepada peserta didik. Artinya bahwa sangat diharapkan kerjasama dari orang tua agar lebih sabar dalam memahami pelajaran yang diberikan oleh guru dari sekolah. Jika ada yang tidak dimengerti mengenai kemampuan belajar para pendidik, bisa berkonsultasi menanyakan bagaimana langkah yang harus dilakukan. Hal ini yang disebutkan dengan bekerja sama antara orang tua peserta didik dengan pendidik, supaya tidak ada kekeliruan dalam mengajar dan membimbing peserta didik untuk menjadi lebih baik.

Beberapa alasan yang mendasari pentingnya keterlibatan orang tua dalam pendidikan adalah dapat mengkomunikasikan dengan baik kepada orang tua tentang kegiatan yang dilakukan oleh anak. Selain itu juga berkontribusi terhadap pencapaian tugas perkembangan anak, baik dalam aspek kognitif maupun aspek perkembangan lainnya. ${ }^{8}$ Dampak yang terjadi

${ }^{5}$ Frederik Patar Hutahaean and Talizaro Tafonao, "Urgenitas Keterlibatan Orang Tua Dalam Menangani Psikologi Anak Selama Belajar Di Masa Pandemi," KAPATA: Jurnal Teologi dan Pendidikan Kristen 2, no. 1 (2021): 13-26.

${ }^{6}$ Safira Rona Mahmudah, "Pengaruh Pembelajaran Daring Terhadap Psikologis Siswa Terdampak Social Distancing Akibat Covid 19," Jurnal Al-Mau'izhoh 2, no. 2 (2020): 1-14.

${ }^{7}$ Rismag Dalena Florentina Monika Br Manurung and Talizaro Tafonao, "Problem Pembelajaran Online Di Masa Pandemi Terhadap Psikologi Anak Usia 10-12 Tahun," Mathetheou: Religios Studies 1, no. 1 (2021): 20 -28. Covid-19.",

${ }^{8}$ Yulianingsih et al., "Keterlibatan Orangtua Dalam Pendampingan Belajar Anak Selama Masa Pandemi 
akibat virus ini antara lain dirasakan juga oleh dunia pendidikan. Semua sekolah dan jenjang pendidikan diminta melakukan pembelajaran jarak jauh atau belajar di rumah untuk memutus rantai virus ini. Banyak faktor yang menyebabkan hal ini menjadi lambat atau bahkan kurang maksimal penerapannya. Faktor tersebut antara lain adalah dari peserta didik yang harus mengganti otomatis suasana belajar mereka menjadi di rumah masing-masing. Peserta didik yang terbiasa dengan lingkungan sekolah yang penuh dengan teman-temannya dan pengalaman mereka yang mereka temui di sekolah, kini berganti menjadi suasana rumah yang dapat dikatakan sebagai suasana nyaman mereka. hal tersebut membuat mereka menjadi semakin dilanda kemalasan karena ada pada suasana nyamannya rumah yang mereka rasakan sejak mereka kecil. Mereka menjadi sulit untuk mengikuti materi atau bahkan menjadi malas untuk belajar. Bisa karena adanya fasilitas seperti gawai atau permainan elektronik, bisa juga karena teman-teman mereka yang juga sedang belajar di rumah sehingga mereka lebih sering bermain dengan teman sebayanya tersebut. Untuk itu orang tua dituntut terus mendampingi anakanaknya sekalipun hal ini menjadi guru dadakan tetapi demi keberlangsungan pembelajaran bagi anak harus dilakukan dan diupayakan dengan menyediakan segala fasilitas yang diperlukan seperti telepon selular (ponsel) yang berbasis android untuk media sambungan internet dalam mendukung proses pembelajaran selama pandemi. ${ }^{9}$ Berdasarkan penjelasan dan pokok permasalahan di atas maka tujuan dalam penulisan artikel ini adalah melihat langkah-langakah apa saja yang dilakukan oleh orang tua dalam mendempingi anak selama belajar di masa pandemi.

\section{Metode Penelitian}

Metode penelitian yang digunakan dalam penelitian ini adalah metode kualitatif deskriptif. Metode tersebut merupakan, metode yang digunakan berdasarkan data yang diperoleh dari lapangan penelitian. Lapangan penilitian yang merupakan satuan pendidikan PAUD Cahaya Generasi Bangsa Pontianak yang beralamat dijalan Parit H Husein II, Pontianak Tenggara. Pendekatan kualitatif memiliki beberapa strategi yang spesifik, yang dalam penelitian ini menggunakan studi fenomenologis. Creswell menyatakan bahwa studi fenomenologis memberikan pemaknaan umum dari sejumlah individu terhadap berbagai pengalaman hidup terkait konsep dan fenomena. ${ }^{10}$

Di masa pandemi seperti ini sekolah tersebut juga termasuk dalam sekolah yang mengadakan pembelajaran daring. Semua siswa yang ada di sekolah tersebut belajar di ruamh dan mengadakan pembelajaran secara daring di rumah. Waktu pelaksanaan penelitian ini adalah pada hari selasa setiap minggunya. Ketentuan yang terdapat pada pedoman PLP daring,

\footnotetext{
${ }_{9}$ Yasanto Lase and Talizaro Tafonao, "Peran Orang Tua Dan Pemerintah Dalam Mendampingi Psikologi Anak Selama Belajar Online," Davar: Jurnal Teologi 2, no. 1 (2021): 1-16.

${ }^{10}$ Saripah Anum Harahap, Dimyati Dimyati, and Edi Purwanta, "Problematika Pembelajaran Daring Dan Luring Anak Usia Dini Bagi Guru Dan Orang Tua Di Masa Pandemi Covid 19," Jurnal Obsesi : Jurnal Pendidikan Anak Usia Dini 5, no. 2 (2021): 1825-1836.
} 
penelitian dilakukan sebanyak 5 pertemuan yang dilakukan secara daring melalui aplikasi zoom, grup whatapps dan Google Classroom.

\section{Hasil dan Pembahasan}

\section{Mengajar dengan cara bekerjasama sama orang tua dan siswa}

Selama pandemi pola belajar anak di lakukan oleh guru secara dari. Artinya anak mengerjakan tugas di rumah. Secara teknis adalah tugas dikirim oleh pihak sekolah melalui grup whatsapp orang tua dan guru. Tugas sekolah dibagikan oleh guru didalam grup whatsapp supaya orang tua dapat mengakses tua dan bisa diprint sendiri, terus dibagikan kepada anak supaya dikerjakan. Tugas sekolah tersebut dikerjakan perhari sesuai dengan tanggal yang sudah ditulis dilembaran kerja anak, yaitu hari senin sampai hari jumaat. Hal itu disamakan oleh guru berdasarkan jadwal sekolah anak yang biasa dilaksanakan. Tugas yang sudah selesai dikerjakan akan dikumpulkan oleh orang tua disimpan dalam satu map atau file map yang akan diserahkan kembali kepada guru. Dalam hal ini orang tua dibekali rencana pelaksanaan Pembelajaran Harian, yang dilakukan oleh guru, supaya orang tua dapat mendampingi anak selama belajar dari rumah. Rencana pelaksanaan pembelajaran harian adalah petunjuk yang berisi cara-cara mempersiapakan pelajaran bagi anak saat pendampingan, pola ini yang diberlakukan orang tua kepada anak saat kerjakan aktivitas sekolah.

Rencana pelaksanaan pembelajaran harian terkadang berubah, hal ini disesuaikan dengan jadwal tugas sekolah agar dapat dikerjakan secara teratur dan orang tua dapat mengarahkan anak-anak dalam mengerjakan tugas sekolah. Demikian juga orang tua perlu mengambil foto atau video anak yang sedang mengerjakan tugas sesuai panduan pelaksanaan ppembelajaran harian dirumah. Kemudian hasilnya dikirim oleh orang tua ke guru melalui grup whatsapp sekolah. Sepanjang pembelajaran dari rumah, orang tua perempuan atau ibu yang lebih banyak mendampingi anak-anak dalam kegiatan pembelajaran ini sedangkan orang tua laki-laki atau bapak melakukan pekerjaan diluar. Dikarenakan anak-anak rasa nyaman bila didampingi oleh ibu.

Berbeda dengan orang tua yang keduanya melakukan pekerjaan di luar, maka anggota keluarga yang lain dapat terlibat mendampingi anak selama belajar dari rumah seperti kakak, tante dan lain-lain yang satu rumah dengan anak yang sedang belajar daring. Anggota keluarga atau orang tua yang terlibat mendampingi selama pembelajaran daring berlangsung, akan diberi tahu cara-caranya dalam pendampingannya dan persiapan-persiapan seperti anak terlebih dahulu mandi dan berpakaian yang bersih, mempersiakan ruangan belajar, alat tulis yang berhubungan dengan tugas sekolah yang akan dikerjakan, hanphone, laptop, tablet dan komputer. Hal lain yang perlu dilakukan orang tua adalah mempersiapkan dirinya dalm mempelajari materi yang akan diajarkan kepada anak. Fungsi orang tua sangat penting dalam mendampingi anak saat belajar dapat mengimplementasikan pelajaran kepada anak. Orang tua juga melakukan komunikasi dengan pihak sekolah untuk penjelasan pengerjaan tugas yang diberikan. Dalam wawancara terdapat beberapa orang tua yang menyatakan bahwa lebih baik 
anak belajar di sekolah daripada di rumah sebab orang tua merasa lebih sulit mengajarkan anak untuk memahami tugas sekolah.

Tantangan lainnya adalah mood atau suasana hati anak yang berubahubah, anak mulai mengalami kebosanan di rumah dan lebih senang jika belajar bersama dengan teman. Hal ini juga diungkapkan oleh anak dalam wawancara bahwa mereka lebih senang jika belajar bersama dengan temannya di sekolah. Belajar secara mandiri di rumah membuat anak menjadi kurang tertantang. Anak pun mulai mengalami kebosanan dan mengalihkan rasa bosan tersebut dengan melakukan hal-hal yang menyenangkan bagi dirinya sendiri, seperti olahraga, main bonekaboneka. Cara lain juga dengan menyalurkan hobi seperti menggambar dan mewarnai. Pihak sekolah selama anak belajar dari rumah tetap aktif menyiapkan materi ajar, LKH dan RPPH yang akan dikirimkan kepada orang tua dan anak. Pihak sekolah pun melakukan komunikasi dengan orang tua melalui telepon, video call, dan chat melalui whatshapp. Hal lainnya adalah para guru mengunjungi rumah masing-masing anak guna menanyakan perkembangan belajar anak dari para orang tua. Dalam video call pihak sekolah merangkainya dengan cara membuat kelompok yang terdiri dari beberapa orang tua. Tujuannya agar pihak sekolah dan sesama para orang tua akan saling berbagi pengalaman selama terlibat mendampingi anak belajar dari rumah. Menurut Anggara bahwakerja sama orang tua dan guru merupakan sebuah hubungan antara guru dan orangtua dalam mendidik, memantau serta mengajar kepada anak guna meningkatkan kemampuan anak dalam bidang akademik maupun akhlaknya. ${ }^{11}$

\section{Bentuk pendampingan Orang Tua Dalam Pembelajaran}

Usia dini bagi manusia ialah masa yang sangat penting. Anak-anak pada masa ini disebut sebagai organisme yang sedang berada dalam tahap perkembangan yang cukup signifikan dari setiap aspeknya. Pada usia dini juga sering disebut dengan masa emas, hal ini disebabkan pada saat anak masih berusia dini anak menjalani suatu proses penting dalam sejarah kehidupannya yang akan berpengaruh pada masa depannya nanti. Pada masa usia dini perkembangan yang terjadi pada anak bisa terlihat dengan jelas, mulai dari bentuk tubuh yang menyangkut tinggi badan maupun berat badan serta kematangan dari setiap fungsi organ tubuh anak, selain itu juga pada usia dini merupakan masa yang sangat sesuai untuk mengajarkan tentang kepribadian atau sikap agar anak memiliki dan memahami nilai-nilai karakter yang baik yang tertanam dalam dirinya.

Pembelajaran merupakan proses internalisasi ilmu pengetahuan ke dalam skemata pelajar. Pada proses ini terdapat aktivitas siswa sebagai pelajar dan terdapat aktivitas guru sebagai pembelajar. Pembelajaran dilakukan dengan tahap perencanaan, pelaksanaan, dan evaluasi oleh pendidik kemudian diaplikasikan melalui pertemuan klasikal dengan didukung media, alat, dan bahan yang sesuai. Tugas guru sebagai pembelajar adalah sebagai pengendali atau pengarah keterampilan dan pengetahuan yang akan dikuasai siswa. Sementara itu, siswa sebagai pelajar

${ }^{11}$ Dony Dwi Anggara, "Kerja Sama Orang Tua Dan Guru Dalam Meningkatkan Kemandirian Belajar Masa Pandemi Covid-19 (Studi Kasus Siswa Kelas V MIN2 Bangkalan)” (UIN SUNAN APEL Surabaya, 2020). 
berperan aktif dalam melaksanakan instruksi guru untuk menuntaskan tujuan pembelajaran yang tercermin dari indikator pencapaian kompetensi. Beradasarkan pernyataan ini, pembelajaran dapat diartikan sebagai proses internalisasi ilmu pengetahuan yang terjadi di dalam kelas yang melibatkan guru dan siswa dibatu dengan media, alat, metode, dan bahan yang telah dirancang berdasarkan standar pendidikan Indonesia dan pola pengembangan kurikulum 2013.

Belajar merupakan kegiatan untuk memperoleh ilmu pengetahuan. Belajar merupakan satu faktor yang berperan penting dalam pembentukan pribadi dan perilaku individu. ${ }^{12}$ Macam macam cara belajar yang dapat dilakukan, baik dengan membaca, mendengar, melihat dan merasa. Semua aktivitas ini dilakukan manusia dalam rangka belajar, baik secara formal, informal, maupun non formal. Khusus untuk pendidikan formal, yaitu pendidikan yang dilaksanakan di lembaga sekolah, maka semua aktivitas belajar tersebut pada prinsipnya untuk satu tujuan, pencapaian prestasi belajar, baik dalam bidang kognitif, afektif, maupun psikomotor. Prestasi belajar adalah tingkah laku anak dalam memperlajari pelajaran di sekolah yang dinyatakan dengan skor, yang diperoleh dari hasil tes mengenai sejumlah materi pelajaran. Jadi, prestasi belajar yang dicapai anak dapat diketahui dengan pencapaian nilai ujian yang diperoleh anak, baik ujian yang berbentuk tes maupun non tes, baik yang bersifat formatif maupun sumatif.

Namun dalam penelitian ini selain ingin melihat proses pembelajaran anak peran dan pola asuh atau pendampingan orang tua kepada anak-anaknya selama pembelajaran daring yang ingin diamati secara seksama. Sebagian orang tua merasa selama pembelajaran jarak jauh tetap dapat meningkatkan keaktifan anak dalam belajar namun, sebagaian orang tua lain menganggap pembelajaran dari tidak efektif karena mengganggu pekerjaan mereka sebagai orang tua apalagi orang tua yang bekerja dan tidak memiliki asisten rumah tangga. Selain itu, tidak semua rumah terdapat fasilitas yang sama antar satu sama lain terutama memiliki gawai, komputer, laptop, dan jaringan internet. Dilihat dari keaktifan peserta didik tidak semua peserta didik selama mengikuti kegiatan pembelajaran daring mengikuti kegiatan dengan aktif. Dari hal ini mungkin disebabkan oleh beberapa faktor diantaranya cara pengajaran guru yang monoton, tidak adanya aplikasi yang memadai, tidak ada jaringan internet dan sebagainya. Oleh karena itu, orang tua harus berperan aktif dan menanyakan kepada anak dan hal ini bersifat baik karena dapat menumbuhkan kedekatan yang lebih anatar orang tua dan anak. Di setiap permasalahan pasti selalu menimbulkan hal positif lainnya. Jika ada orang tua yang bekerja maka selama masa pandemi bekerja di rumah dan dapat membantu anak dalam hal belajar dan bermain. Oleh sebab itu, anak kembali merasa dekat dengan orang tua. Namun, kelemahannya ada beberapa orang tua yang tidak sabar dalam menghadapi anak ketika belajar. Faktor ini disebabkan beberapa hal, mulai dari perbedaan tingkat jenjang pendidikan yang ditempuh orang tua, sifat kesabaran orang tua dalam membimbing anak, dan jiwa "guru" yang dimiliki tiap orang tua berbeda. Tidak

\footnotetext{
${ }^{12}$ Yulianingsih et al., "Keterlibatan Orangtua Dalam Pendampingan Belajar Anak Selama Masa Pandemi Covid-19."
} 
sedikit orang tua yang menyewa jasa guru privat untuk menemani anak-anak mereka karena disebabkan oleh faktor-faktor tersebut.

Selain itu faktor pentingnya orang tua dalam mendampingi anak selama pembelajaran daring adalah karena guru rata-rata hanya memiliki waktu pengajaran satu hingga satu setengah jam dan materi yang disampaikan terkesan setengah-setengah. Para orang tua wajib mempelajari materi pelajaran terlebih dahulu agar sewaktu pembelajaran antara peserta didik dan guru sedang berlangsung orang tua dapat memahaminya juga. Akan tetapi, tidak semua guru menerapkan model pembelajaran daring atau memberikan materi terlebih dahulu ada yang hanya memberikan tugas saja. Hal ini juga menjadi catatan penting karena peserta didik perlu pemahaman secara nyata dan ketika guru tidak memberikan pemahaman tersebut maka perannya otomatis tergantikan oleh orang tua itu sediri. Perlu di garis bawahi juga tidak semua orang tua memahami betul apa mata pelajaran yang sedang berlangsung, karena tidak semua orang tua mengenyam pendidikan yang setara oleh sebab itu hal ini masih menjadi kendala karena peserta didik tidak ada yang menjadi pembimbingnya selama mengikuti pembelajaran. Tidak sedikit tugas yang diberikan oleh guru malah dikerjakan oleh orang tua bukan peserta didik. Hal ini disebabkan guru tidak memiliki inisiatif lain dalam memberika materi pembelajaran dan peserta didik tidak mengerti sehingga orang tua harus turun tangan.

Orang tua bisa menerapkan metode pengajaran yang melibatkan kegiatan sehari-hari seperti membuat makanan, membersihkan rumah, atau lainnya yang bisa dikreasikan dengan materi yang sedang dipelajari oleh anak. Agar anak tidak merasa jenuh dan merasa bahwa selama masa pandemi ini mereka kegiatannya hanya berkutat dengan mengerjakan tugas dan tugas. Hal penting yang perlu diingat oleh orang tua juga adalah jika dirasa guru terlalu banyak memberikan tugas kepada anak-anak mereka segera beritahu guru tersebut. Anak tidak akan bisa menyampaikan pesan tersebut kepada guru mereka karena merasa canggung namun orang tua bisa menjadi perantara anak untuk menyampaikan pesan. Selama melawati masa-masa sulit ini yang dibutuhkan anak adalah pembelajaran yang menyenangkan. Orang tua juga dapat melihat perkembangan anak-anak mereka sendiri selama pembelajaran daring di rumah. Tidak seperti sebelum-sebelumnya orang tua hanya melihat hasil pembelajaran anak dari rapor namun kali ini dapat mengetahui setiap perkembangan mengenai pengetahuan dan keterampilan yang dimiliki oleh anak-anak mereka.

Dari hal ini memperlihatkan bawah orang tua tetap menjadi teladan bagi peserta didik. Bukan hanya guru yang menjadi panutan di sekolah kali ini peran orang tua yang lebih banyak mengambil tempat di dalamnya. Selain itu dari masa pandemi covid-19 ini orang tua menjadi sadar akan pentingnya teknologi yang dibutuhkan di era sekarang bukan lagi persoalan sekolah dengan buku tulis sidu dan pensil 2B. Hal ini juga bisa menjadi cambuk dan pembelajaran yang berharga bagi pemerintah Indonesia untuk meningkatkan lagi pendidikan kita mulai dari materi, insfrastruktur, pengajar, hingga teknologi atau media pemebelajaran yang digunakan dan memperbaiki segala hal yang terjadi di dalam permasalahan pendidikan Indonesia agar tidak tertinggal semakin jauh dengan negara-negara lainnya. 


\section{Metode Pendampingan orang tua dalam pembelajaran}

Pendampingan adalah suatu upaya memfasilitasi suatu individu dalam mengatasi masalah atau hubungan timbal balik antara individu tersebut. Pendampingan kepada anak sangat dibutuhkan terhadap orangtua karena anak cenderung membutuhkan perhatian atau komunikasi kepada orang tua. Pendampingan anak di dalam keluarga merupakan upaya bantuan yang dilakukan pihak keluarga khususnya orang tua dengan mendampingi anak untuk memenuhi kebutuhan dan pemecahan masalah anak dalam rangka mendukung optimalisasi perkembangan anak. Pendampingan orang tua dalam proses belajar anak adalah upaya orang tua untuk menemani, memberikan bantuan dalam mengatasi masalah anak dalam belajar, memberikan dorongan, motivasi, dukungan, pengawasan dan memberikan fasilitas pada anak agar semangat dalam belajar.

Menurut Hwie (dalam Prasetyo, 2018, hlm. 23) ada beberapa aspek yang dapat dilakukan oleh orang tua dalam membantu belajar anak yaitu: ${ }^{13}$

1. Menyediakan fasilitas belajar Fasilitas yang dimaksud adalah tempat belajar, alat tulis, buku-buku pelajaran, dan lain-lain. Fasilitas belajar ini dapat membenatu memudahkan siswa dalam proses belajar sehingga siswa tidak mendapatkan hambatan dalam belajar.

2. Mengawasi kegiatan belajar anak di rumah Orang tua perlu mengawasi kegiatan belajar di rumah karena dengan mengawasi kegiatan belajar anak, orang tua dapat mengetahui apakah anak mereka sudah belajar dengan baik ataupun belum. Melalui pengawsan orang tua anak dapat belajar dengan teratur, apabila mendapatkan pekrjaan rumah (PR) dapat langsung mengerjakannya tanpa menunda.

3. Mengawasi penggunaan waktu belajar anak di rumah Orang tua perlu mengawasi kegiatan belajar anak di rumah,apakah anak sudah menggunakan waktu belajarnya dengan baik atau belum. Orang tua dapat membantu anak menyusun jadwal belajar.

4. Mengawasi kesulitan dalam mengatasi kesulitan dalam belajar Untuk membantu dalam proses pendidikan, orang tua ikut serta dalam proses belajar, termasuk mengetahui cara yang digunakan untuk membantu anak dalam belajar. Semakin banyak pengetahuan orang tua, maka akan semakin banyak materi yang diberikan kepada anakanaknya. Bertambahnya pengetahuan orang tua juga akan memudahkan anak dalam mencari tempat jawaban dari setiap pertanyaannya.

5. Menolong kesulitan yang dihadapi anak dalam belajar Orang tua perlu mengenal atau mengetahui kesulitan yang dihadapi anak dalam belajar, karena dengan mengetahui kesulitan tersebut, orang tua mampu membantu menyelesaikannya. Apabila orang tua tidak mengenali kesulitan yang dihadapi anak dalam belajar, maka proses belajar anak akan terhambat.

Peran orangt ua dalam mendampingi ketika mengajarkan anak-anaknya, para orang tua juga harus melihat mood anak karena terkadang anak mudah merasa bosan dengan metode

\footnotetext{
${ }^{13}$ Nisa Fitri Andhini, “Kajian Teori Dan Kerangka Pemikiran A.” 53, no. 9 (2017): 1689-1699.
} 
pembelajaran yang selalu monoton, sehingga ketika anak sudah tidak mood lagi untuk belajar maka pembelajaran menjadi tidak efektif. Kejadian-kejadian ini terkadang membuat beberapa ibu berkomentar bahwa lebih baik anaknya diajarkan oleh gurunya saja supaya anak takut karena jika diajarkan oleh orangtua yang ada anak malah kebanyakan bermain. Menurut Papalia, bermain adalah pekerjaan seorang anak, dan hal ini berkontribusi terhadap seluruh perkembangan anak. Melalui bermain anak merangsang indra, belajar menggunakan otot-otot mereka, mengkoordinasikan penglihatan dan gerakan, memperoleh penguasaan tubuh dan memperoleh keterampilan baru. ${ }^{14}$ Oleh karena itu agar pembelajaran pada anak tidak membosankan bagi anak maka orang tua harus mampu menciptakan pembelajaran yang menyenangkan bagi anak.

\section{Dampak Pendampingan Orang Tua Dalam Pembelajran}

Pelaksanaan pembelajaran dirumah, banyak dari orang tua memberikan motivasi selama siswa dituntut untuk belajar dari rumah karena himbauan pemerintah mengenai covid-19, hal ini juga yang membuat tidak sedikit orang tua yang sengaja untuk meluangkan waktunya demi dapat membantu proses pembelajaran anaknya selama di rumah. Banyak dari orang tua yang setuju jika selama pembelajaran di rumah, orang tua lah yang juga ikut membantu mengerjakan tugas yang diberikan oleh guru. Menurut Subarto, dalam proses pembelajaran di rumah, pastilah anak mengalami kecemasan, stress, sedih, bosan, jenuh, dan perasaan lainnya ${ }^{15}$. Dengan hal seperti ini, anak membutuhkan peran orang tua agar anak memiliki self-regulating sehingga mampu mengajarkan dirinya dalam upaya memberikan penguatan secara internal. Disinilah letak fungsi dan tanggung jawab orang tua, yakni membesar, mendidik, membimbing dan memenuhi kebutuhan dasar anak sesuai kebenaran. ${ }^{16}$ Dan ini adalah inti perintah Tuhan kepada setiap umat manusia, yakni membawa keluarga kepada Tuhan untuk dididik (memuridkan) sesuai nilai-nilai kekristenan. ${ }^{17}$ Jika hal ini dilakukan sebagai penguatan didalam diri anak dan sesuai dengan tugas-tugas pembelajaran yang dijalaninya, maka anak mengalami dampak secara signifikan bagi dirinya.

\section{Kesimpulan}

Dengan adanya kebijakan dari pemerintah untuk work form home dan belajar di rumah, maka peran orang tua sebagai pengganti guru sangat penting. Peran orang tua juga sangat

${ }^{14}$ Fransiska Program et al., "Peran Orang Tua Dalam Kegiatan Belajar Di Rumah Pada Masa Pandemi Covid-19 (Studi Kasus Pada Anak Usia 5-6 Tahun)," DUNIA ANAK : Jurnal Pendidikan Anak Usia Dini 3, no. 1 (2020): 15-27.

${ }^{15}$ Nika Cahyati and Rita Kusumah, "Peran Orang Tua Dalam Menerapkan Pembelajaran Di Rumah Saat Pandemi Covid 19,” Jurnal Golden Age, Universitas Hamzanwadi 04, no. 1 (2020): 152-159.

${ }^{16}$ Ida Bagus, Nyoman Widiartawan, and Talizaro Tafonao, "Peranan Dan Kedudukan Orang Tua Di Tengah Keluarga Dan Gereja Sebagai Pendidik The Role and Position of Parents in The Middle of The Family and The Church As Educators," jurnal SHAMAYIM 1, no. 2 (2021): 188-203.

${ }^{17}$ Fransiskus Irwan Widjaja, "Keluarga Yang Misioner," in Prosiding Seminar Nasional: Keluarga Yang Misioner (Kota Batam: STT REAL BATAM, 2020), 31-40. 
diperlukan untuk memberikan edukasi kepada anak-anaknya yang masih belum memahami tentang pandemi yang sedang mewabah untuk tetap berdiam diri di rumah agar tidak tertular dan menularkan wabah pandemi ini. Namun, belajar di rumah juga memiliki kelebihan dan kekurangan. Berdasarkan seluruh hasil penjelasan dalam artikel ini. Pembelajaran di rumah dinilai tetap mampu meningkatkan kualitas pembelajaran. Jika orangtua ikut membantu anak-anak dalam memotivasi selama mengerjakan tugas yang diberikan oleh guru, walaupun tidak sedikit juga yang merasa hal ini menjadi tambahan aktivitas orang tua selain mengerjakan pekerjaan rumah tangga.

Berdasarkan hal maka penulis memberikan saran kepada beberapa pihak diantaranya: orang tua harus memperhatikan anak ketika sedang belajar di rumah agar anak merasa semangat belajar karena anak merasa bahwa bukan hanya dirinya yang ingin maju tetapi orang tua berkeinginan yang sama dengan anak dan guru, diharapkan untuk memberikan inovasi pembelajaran agar tidak monoton dalam pembelajaran daring.

\section{Referensi}

Andhini, Nisa Fitri. "Kajian Teori Dan Kerangka Pemikiran A.” 53, no. 9 (2017): 1689-1699. Anggara, Dony Dwi. "Kerja Sama Orang Tua Dan Guru Dalam Meningkatkan Kemandirian Belajar Masa Pandemi Covid-19 (Studi Kasus Siswa Kelas V MIN2 Bangkalan).” UIN SUNAN APEL Surabaya, 2020.

Bagus, Ida, Nyoman Widiartawan, and Talizaro Tafonao. "Peranan Dan Kedudukan Orang Tua Di Tengah Keluarga Dan Gereja Sebagai Pendidik The Role and Position of Parents in The Middle of The Family and The Church As Educators." jurnal SHAMAYIM 1, no. 2 (2021): 188-203.

Cahyati, Nika, and Rita Kusumah. "Peran Orang Tua Dalam Menerapkan Pembelajaran Di Rumah Saat Pandemi Covid 19.” Jurnal Golden Age, Universitas Hamzanwadi 04, no. 1 (2020): 152-159.

Harahap, Saripah Anum, Dimyati Dimyati, and Edi Purwanta. "Problematika Pembelajaran Daring Dan Luring Anak Usia Dini Bagi Guru Dan Orang Tua Di Masa Pandemi Covid 19.” Jurnal Obsesi : Jurnal Pendidikan Anak Usia Dini 5, no. 2 (2021): 1825-1836.

Hutahaean, Frederik Patar, and Talizaro Tafonao. "Urgenitas Keterlibatan Orang Tua Dalam Menangani Psikologi Anak Selama Belajar Di Masa Pandemi.” KAPATA: Jurnal Teologi dan Pendidikan Kristen 2, no. 1 (2021): 13-26.

Iftitah, Selfi Lailiyatul, and Mardiyana Faridhatul Anawaty. "Peran Orang Tua Dalam Mendampingi Anak Di Rumah Selama Pandemi Covid-19.” JCE (Journal of Childhood Education) 4, no. 2 (2020): 71.

Lase, Yasanto, and Talizaro Tafonao. "Peran Orang Tua Dan Pemerintah Dalam Mendampingi Psikologi Anak Selama Belajar Online.” Davar: Jurnal Teologi 2, no. 1 (2021): 1-16.

Mahmudah, Safira Rona. "Pengaruh Pembelajaran Daring Terhadap Psikologis Siswa Terdampak Social Distancing Akibat Covid 19.” Jurnal Al-Mau’izhoh 2, no. 2 (2020): 
$1-14$.

Manurung, Rismag Dalena Florentina Monika Br, and Talizaro Tafonao. "Problem Pembelajaran Online Di Masa Pandemi Terhadap Psikologi Anak Usia 10-12 Tahun.” Mathetheou: Religios Studies 1, no. 1 (2021): 20-28.

Program, Fransiska, Studi Pendidikan, Guru Pendidikan, Anak Usia Dini, Stkip Persada, Khatulistiwa Sintang, and Kalimantan Barat. "Peran Orang Tua Dalam Kegiatan Belajar Di Rumah Pada Masa Pandemi Covid-19 (Studi Kasus Pada Anak Usia 5-6 Tahun)." DUNIA ANAK : Jurnal Pendidikan Anak Usia Dini 3, no. 1 (2020): 15-27.

Sari, Puspita Ria, Nabila Bunnanditya Tusyantari, and Meidawati Suswandari. "Dampak Pembelajaran Daring Bagi Siswa Sekolah Dasar Selama Selama Covid-19 Universitas Veteran Bangun Nusantara, Sukoharjo.” Prima Magistra: Jurnal Ilmiah Kependidikan 2, no. 1 (2021): 9-15.

Suriadi, Harri Jumarto, Firman Firman, and Riska Ahmad. "Analisis Problema Pembelajaran Daring Terhadap Pendidikan Karakter Peserta Didik." Edukatif : Jurnal Ilmu Pendidikan 3, no. 1 (2021): 165-173.

Widjaja, Fransiskus Irwan. "Keluarga Yang Misioner." In Prosiding Seminar Nasional: Keluarga Yang Misioner, 31-40. Kota Batam: STT REAL BATAM, 2020.

Yulianingsih, Wiwin, Suhanadji Suhanadji, Rivo Nugroho, and Mustakim Mustakim. "Keterlibatan Orangtua Dalam Pendampingan Belajar Anak Selama Masa Pandemi Covid-19." Jurnal Obsesi : Jurnal Pendidikan Anak Usia Dini 5, no. 2 (2020): 11381150 . 